\title{
Curricular intervention protocol for teaching learners with Autism Spectrum Disorder: an integrative review
}

\author{
Eduardo Pimentel da Rocha ${ }^{1}$ \\ https://orcid.org/0000-0002-9937-7806 \\ Amanda Tragueta Ferreira-Vasques ${ }^{1}$ \\ https://orcid.org/0000-0003-0489-3611 \\ Dionísia Aparecida Cusin Lamônica1 \\ https://orcid.org/0000-0002-9381-0680
}

Faculdade de Odontologia de Bauru da Universidade de São Paulo, Bauru, São Paulo, Brasil.

Research support source: Coordenação de Aperfeiçoamento de Pessoal de Nível Superior (CAPES).

Conflict of interests: Nonexistent

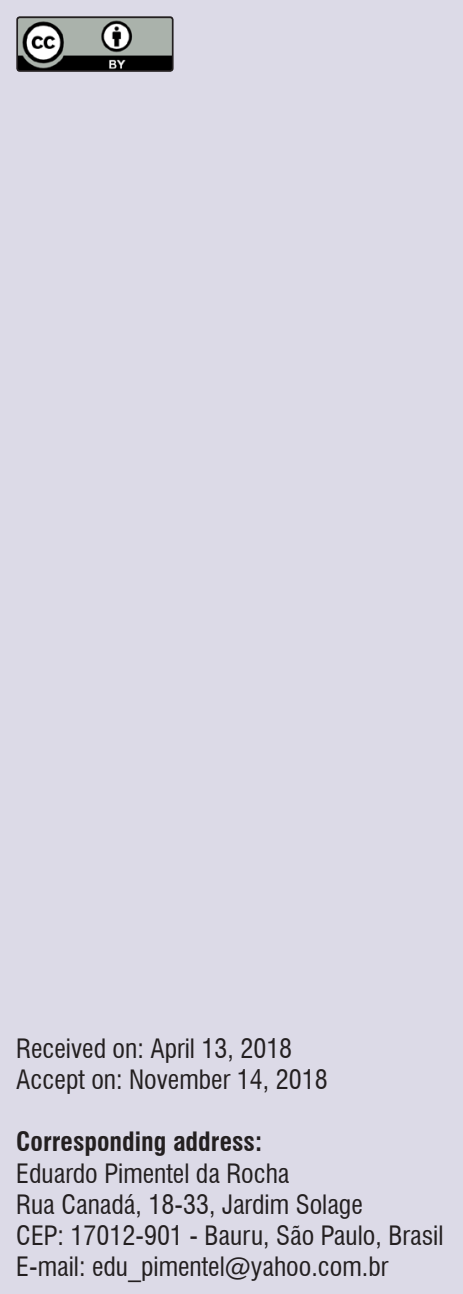

\section{ABSTRACT}

Objective: to conduct an integrative review of scientific papers indexed in national and international databases on curricular intervention protocols, which favor the linguistic aspects, translated and cross-culturally adapted to Brazilian Portuguese for the teaching of individuals with Autism Spectrum Disorder.

Methods: a survey of scientific studies indexed in Pubmed, Portal Regional da Biblioteca Virtual em Saúde, Web of Science, Scopus and ERIC databases was carried out from February to March 2018. Papers in English and Portuguese language of the last 20 years on the proposed theme were selected. The inclusion criteria used were: to be a school curricular intervention protocol that favors the linguistic aspects; to be directed to learners with Autism Spectrum Disorder; to be translated and cross-culturally adapted to Brazilian Portuguese.

Results: 214 papers were analyzed revealing the lack of studies on the topic. These data indicate a gap in national basic education, which may corroborate the low qualitative aspects of inclusive education in the country. The Collaborative Model for Promoting Competence and Success for Students with Autism Spectrum Disorder enables a more effective teaching of learners with autism, since this protocol empowers teachers in curricular adaptation to also develop the language skills and overcome the educational challenges of the students with this condition.

Conclusion: the Brazilian scenario is that of absent instruments, which may interfere with the quality of inclusive education in Brazil.

Keywords: Autistic Disorder; Child Development; Learning; Teaching; Education 


\section{INTRODUCTION}

In the last century, individuals with special needs (SN) gained important social, economic and educational rights, which brought visibility to this population'.

Regarding education, access was achieved through the strengthening of school inclusion policies in Brazil and in the world, which made possible, in an increasingly way, in the last 20 years, that apprentices with various $\mathrm{SN}$ have become part of the regular classrooms ${ }^{2,3}$.

According to an article published by the Portal Brasil do Ministério da Educação, about the inclusive reality in Brazil, in 2014 678,718 thousand students with SN were regularly enrolled in regular classes of basic education in the country ${ }^{4}$.

According to the 2016 Dados do Censo Escolar da Educação Básica of the Instituto Nacional de Estudos e Pesquisas Educacionais Anísio Teixeira (INEP), $57.8 \%$ of the Brazilian primary schools in that year had students with some sort of $\mathrm{SN}$, regularly enrolled ${ }^{5}$.

Although it is difficult to determine the current percentage of students with $\mathrm{SN}$, due to the lack of official data, enrolled in the regular classes of the country, with the expressive number of schools, especially those of the public system, it is inevitable to think about the quality of the teaching offered to them, especially those with Autism Spectrum Disorder (ASD), the focus of this study.

The ASD, which is a neurodevelopmental disorder with an unknown multifactorial cause, has as a characteristic the impairment of the linguistic and social functions in the individuals with this condition. As it is a spectrum, individuals can vary from mild to severe levels, having the total impairment of the aforementioned functions in the most severe cases to the development of high skills and giftedness in milder cases $^{6}$.

The most recent literature on inclusive education in Brazil has pointed to the expansion of educational services that have taken place over the last decades in the country as an important step in the Brazilian educational scenario. However, several authors have warned that it was not accompanied also by a linear evolution in its qualitative aspects ${ }^{7-9}$.

It is considered educational aspects the teacher training, as well as the development of materials, tools, strategies, techniques, among others, that allow the full development of the learner with $\mathrm{SN}$ at their school level.
Considering that in the year 2000, 164 countries, among them Brazil, signed a commitment in Dakar, in the so-called The Dakar Framework for Action, to pursue six goals of education for all by 2015, with one of its main aspects being the quality of education and the fundamental constitutional guarantee for access to quality education, this study aimed to carry out an integrative review of scientific papers indexed in national and international databases on school curricular intervention protocols, that favor the linguistic aspects, translated and cross-culturally adapted to Brazilian Portuguese for the teaching of individuals with ASD.

\section{METHODS}

Considering the inclusion criteria used for the research: 1. to be a school curriculum intervention protocol that favor the linguistic aspects; 2 . to be directed to learners with ASD and; 3 . to be translated and cross-culturally adapted to Brazilian Portuguese; a survey in the databases Education Resources Information Center (Eric), PubMed, Scopus, Portal Regional da Biblioteca Virtual em Saúde (BVS) and Web of Science was carried out, aiming to answer the research question: What are the school curricular intervention protocols translated and cross-culturally adapted to Brazilian Portuguese, that favor the linguistic aspects, available for the use of the Brazilian teachers for the teaching of students with ASD?

The surveys were carried out from February to March 2018, considering the years of 1998 to 2018 of the literature published in Portuguese and English language of the proposed theme.

It should be emphasized that the choice of the aforementioned databases for this research was because they present reliability and prestige in the technicalscientific environment and because they cover health and education areas.

Thus, considering the goal of the research, the Health Sciences descriptors, the terms of the Medical Subject Headings (MeSH) of the National Library of Medicine, the descriptors of the Thesaurus of the ERIC database and the free terms (keywords) that were crossed among them with the use of the Boolean operators AND and OR were established.

The surveys on the databases obeyed the following search order: 1. ERIC; 2. PubMed; 3. Regional Portal da BVS; 4. Scopus and 5. Web of Science. 
Figure 1, below, presents the strategies with the surveys specificities, the descriptors, and the keywords used.

\begin{tabular}{|c|c|c|c|}
\hline Database & Research Specificities & Free terms /Keywords & Descriptors \\
\hline ERIC & $\begin{array}{l}\text { For the survey with the free terms / } \\
\text { keywords, the option "Collection", } \\
\text { "Peer reviewed only" and "Full text } \\
\text { available on ERIC" were selected. For } \\
\text { the search with the descriptors, the } \\
\text { "Thesaurus" option was used. }\end{array}$ & $\begin{array}{l}\text { intervention protocol OR educational } \\
\text { framework AND autism }\end{array}$ & $\begin{array}{l}\text { educational counseling OR } \\
\text { curriculum adaptation AND autism }\end{array}$ \\
\hline PubMed & $\begin{array}{l}\text { For the survey with the free terms } \\
\text { / keywords, the "All fields" option } \\
\text { was used. For the search with the } \\
\text { descriptors, the "MeSH Terms" option } \\
\text { was used. }\end{array}$ & $\begin{array}{c}\text { (((educational framework) OR } \\
\text { (curricula AND teaching method)) } \\
\text { AND autism) }\end{array}$ & $\begin{array}{l}\text { (autism spectrum disorder[MeSH } \\
\text { Terms]) AND (((curriculum[MeSH } \\
\text { Terms]) AND teaching[MeSH Terms]) } \\
\text { AND models, educational[MeSH } \\
\text { Terms]) }\end{array}$ \\
\hline $\begin{array}{l}\text { Portal Regional } \\
\text { da BVS }\end{array}$ & $\begin{array}{l}\text { The "Title, abstract and subject" } \\
\text { option in the advanced search field } \\
\text { was used for the survey. }\end{array}$ & $\begin{array}{c}\text { autismo OR Transtorno do Espectro } \\
\text { Autista AND protocolo de intervenção } \\
\text { escolar OR protocolo de intervenção } \\
\text { AND currículo }\end{array}$ & $\begin{array}{c}\text { Transtorno do Espectro Autista AND } \\
\text { currículo }\end{array}$ \\
\hline Scopus & $\begin{array}{l}\text { The "Title, abstract and Keywords" } \\
\text { option was used for the survey. }\end{array}$ & $\begin{array}{c}\text { autism spectrum disorder AND } \\
\text { curricula AND adaptation }\end{array}$ & * \\
\hline $\begin{array}{l}\text { Web of } \\
\text { Science }\end{array}$ & $\begin{array}{l}\text { The "topic" option was used for the } \\
\text { search. }\end{array}$ & $\begin{array}{l}\text { Autism Spectrum Disorder AND } \\
\text { curricula AND intervention protocol }\end{array}$ & * \\
\hline
\end{tabular}

Note: * - the databases do not present a list of descriptors and therefore the surveys were not carried out.

Figure 1. Database Search Strategies

The total results found by databases are shown in Figure 2.

\begin{tabular}{|c|}
\hline Total papers retrieved \\
214 \\
\hline
\end{tabular}

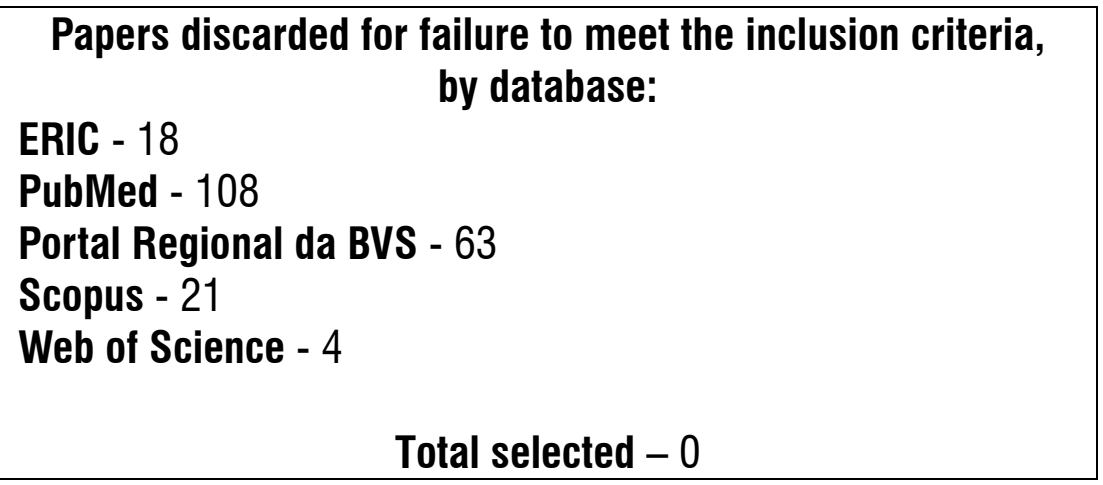

Figure 2. Flowchart of the analysis of papers retrieved in the databases, according to the inclusion criteria 
As shown in Figure 2, 214 papers were retrieved in the different databases and after verifying whether or not the studies met the inclusion criteria proposed for the research, all papers were excluded.

\section{LITERATURE REVIEW}

The integrative review of the last 20 years on the theme of this study in the databases chosen for this research showed, with the application of the inclusion criteria, the lack of scientific papers on school curricular intervention protocols, which favor the linguistic aspects, translated and cross-culturally adapted to Brazilian Portuguese for the teaching of individuals with ASD.

Considering the 214 papers retrieved from the databases, none met the three pre-established inclusion criteria. However, a descriptive qualitative analysis of four school curricular intervention protocols directed to students with ASD found in the databases surveys, which approximates to the chosen inclusion criteria, is made. It is noteworthy that, despite this description, the studies were discarded from this research because they did not meet concomitantly the three inclusion criteria proposed.

Regarding the four studies on school curricular intervention protocols, the first one was about the application of the Accessible Literacy Learning ${ }^{10}$ (ALL) in the teaching of phonemes for eight individuals, from eleven to sixteen years old, with the diagnosis of ASD, Rett Syndrome, Down syndrome, cerebral palsy and intellectual disability. The results pointed to a moderate evidence of the functional relationship between the use of this curriculum and the participants' progress concerning to phonemes learning.

Dixon et al. (2017) described the feasibility of Promoting the Emergency of Advanced Knowledge ${ }^{11}$ (PEAK) in the teaching of complex verbal operators for three children with ASD. After the PEAK application, the results indicated that each participant successfully acquired the directly trained behaviors and demonstrated generalization for the non-reinforced test samples.

Two studies presented proposals that were closer to the objective of this study, although they were not cross-culturally adapted to Brazil.

Young et al. (2015) applied the Comprehensive Autism Program ${ }^{12}$ (CAP) in the teaching of apprentices, from three to five years of age, diagnosed with ASD. The study had the participation of 84 teachers and 302 students with ASD and their parents. The results revealed that CAP had small positive impacts on students' receptive language and their abilities.

Another study analyzed the application of the Preschool Inventory of Repertoires for Kindergarten ${ }^{13}$ (PIRK) in the teaching of apprentices with ASD in two distinct stages. The first one referred to the application of PIRK as a curriculum for special education schools and if this instrument could have an impact on the development of learners with ASD. The second stage aimed to investigate the ability of children to move from special schools to regular schools. The results from the first stage pointed to an increase in school development of both groups that participated in the research, however, the children who received the PIRK curriculum had better results in areas such as behavior management and social integration skills. The results from the second stage suggest that children who previously received PIRK, to attend regular schools, showed improvements in communication, socialization, and daily life skills.

The other studies found, discarding those that did not correspond to the school aspect, were, in large part, about teaching strategies and/or curricular adaptations directed to parents and caregivers of children with ASD.

Considering the current reality of educational policies for inclusion in Brazil, as well as the reality of Brazilian public schools, as pointed by the INEP Census in 2016, this finding reveals a gap in the qualitative aspects of Brazilian basic education ${ }^{7-9}$, despite achievements regarding the school inclusion of individuals with $\mathrm{SN}^{1-3}$ guaranteed by national legislation $\mathrm{n}^{4,5,14-19}$.

The requirement for the inclusion of individuals with $\mathrm{NE}$ as recommended in the documents and laws ${ }^{16-19}$ that guide national basic education, especially those with ASD, presuppose, theoretically and practically, that teachers and schools will be provided with strategies, materials and instruments that can promote the educational development of these learners ${ }^{18,19}$.

In this sense, the use of school curricular intervention protocols can make feasible and allow a more inclusive practice from teachers and collaborate in improving the qualitative aspects of basic education in the country, especially considering the specific characteristics ${ }^{6}$ of learning, in this case those regarding language, individuals with TEA.

Being language an essential element of human development and impaired in individuals with ASD, it is imperative that this aspect be stimulated and be part of the learner's school activities. 
In the international scenario, there is a school curricular intervention protocol called Collaborative Model for Promoting Competence and Success for Students with Autism Spectrum Disorder (COMPASS) ${ }^{20}$ which is also directed to favor and to develop the linguistic aspects of the ASD student.

The above-mentioned protocol developed by Ruble et al., of the Kentucky University in the United States, has been used in American school contexts, benefiting ASD students' academic and linguistic development ${ }^{21-23}$.

Because it is scientifically tested, systematized and based on evidence ${ }^{16}$, and because it considers the characteristics of the ASD apprentice for the development of curricular interventions that allow the development of this student, in linguistic and social areas, based on the school curriculum ${ }^{21-23}$, COMPASS can assist Brazilian teachers in their practices.

Nowadays, the translation and cross-cultural adaptation of COMPASS $^{20}$ to Brazilian Portuguese are being conducted in order to make this instrument available to teachers of basic education in Brazil.

\section{CONCLUSION}

An integrative review of the literature on school curricular intervention protocols, which favor the linguistic aspects, for ASD students was carried out.

The absence of these protocols in the investigated scenario, that can interfere in the quality of inclusive education in Brazil, was verified.

\section{ACKNOWLEDGEMENTS}

This study was financed in part by the Coordenação de Aperfeiçoamento de Pessoal de Nível Superior Brasil (CAPES) - Finance Code 001.

\section{REFERENCES}

1. Tonelli JRA, Rocha EP, Ferreira OHS, Oliveira TRR. O currículo adaptado: (re)pensando o ensino de línguas estrangeiras para aprendizes com necessidades educacionais especiais a partir da sequência didática. Revelli. 2017;9(2):97-109.

2. Rebelo ASA. Educação especial no Brasil: indicadores educacionais de atendimento especializado (1973-2014). [tese]. Mato Grosso do Sul (MS): Universidade Federal de Mato Grosso do Sul, Pós-Graduação em Educação; 2016.

3. Mendes RS. A escolarização de alunos com deficiência intelectual no ensino fundamental da rede de ensino de Itajaí - SC [dissertação]. Itajaí (SC): Universidade do Vale do Itajaí; 2016.
4. Brasil: Portal Brasil. Dados do Censo Escolar indicam aumento de matrícula de alunos com deficiência. [acesso $19 \mathrm{dez}$ 2017]. Disponível em: http://www.brasil.gov.br/educacao/2015/03/dadosdo-censo-escolar-indicam-aumento-de-matriculasde-alunos-com-deficiencia

5. Brasil: Instituto Nacional de Estudos e Pesquisas Educacionais Anísio Teixeira (INEP). Censo Escolar da Educação Básica 2016 - Notas Estatísticas. [acesso 19 dez. 2017]. Disponível em: http:// download.inep.gov.br/educacao_basica/censo_ escolar/notas_estatisticas/2017/notas_estatisticas_ censo_escolar_da_educacao_basica_2016.pdf

6. Apa (Associação Americana de Psiquiatria). Manual Diagnóstico e Estatístico - DSM-V. Porto Alegre: Artes Médicas; 2013.

7. Dall'Acqua MJC, Vitaliano CR. Algumas reflexões sobre o processo inclusivo em nosso contexto educacional. In: Vitliano CR (org). Formação de professores para a inclusão de alunos com necessidades educacionais especiais. Londrina: EDUEL, 2010. p. 17-31.

8. Ferreira JR, Ferreira MCC. Sobre inclusão, políticas públicas e práticas pedagógicas. In: Góes MCR, Laplane ALF (org). Políticas e práticas de educação inclusiva. Campinas: Autores Associados, 2013. p. 21-46.

9. Costa DS, Medrado BP, Quirino IJL. Saberes Docentes em um Contexto Inclusivo de Ensino de Língua Inglesa a Alunos com Deficiência Visual. [acesso 29 fev. 2016]. Disponível em: http:// editorarealize.com.br/revistas/cintedi/trabalhos/ Modalidade_1datahora_31<_10_2014_01_12_53_ idinscrito_2709_04fe3c887f96ac50cc8f6f8a724 912aa.pdf

10. Ainsworth MK, Evmenova AS, Berhmann M, Jerome M. Teaching phonics to groups of middle school students with autism, intellectual disabilities and complex communication. Res Dev Disabil. 2016;56:165-76.

11. Dixon MR, Peach J, Daar JH, Penrod C. Teaching complex verbal operants to children with autism and establishing generalization using the PEAK curriculum. J Appl Behav Anal. 2017;2(50):317-31 .

12. Young HE, Falco RA, Hanita M. Randomized, controlled trial of a comprehensive program for young students with autism spectrum disorder. $\mathrm{J}$ Autism Dev Disord. 2016;46(2):544-60.

13. Waddington EM, Reed P. The impact of using the "Preschool Inventory of Repertoires for 
Kindergarten" (PIRK) on school outcomes of children with Autistic Spectrum Disorders. Res Autism Spectr Disord. 2009;3(3):809-27.

14. Pletsch MD. Repensando a inclusão escolar: diretrizes políticas, práticas curriculares e deficiência intelectual. Rio de Janeiro: Nau, 2014.

15. Pletsch MD. A escolarização de pessoas com deficiência intelectual no Brasil: da institucionalização às políticas de inclusão (19732013). Revista Arquivos Analíticos de Políticas Educativas [periódico na internet]. 2014 [acesso 09 fev. 2018]; 22 (81): 1-29. Disponível em: http:// epaa.asu.edu/epaa/v22n81

16. Brasil. Política Nacional de Educação Especial na perspectiva da Educação Inclusiva. [acesso 19 dez. 2017]. Disponível em: http:// portal. mec.gov.br/index.php?option $=\mathrm{com}_{-}$ docman\&view $=$ download\&alias $=16690$-politicanacional-de-educacao-especial-na-perspectiva-daeducacao-inclusiva-05122014\&ltemid $=30192$

17. Brasil. Diretrizes Operacionais para o Atendimento Educacional Especializado na Educação Básica, modalidade Educação Especial - Resolução 4. [acesso $19 \mathrm{dez}$. 2017. Disponível em: http://portal. mec.gov.br/dmdocuments/rceb004_09.pdf

18. Brasil. Lei no 12.796, de 4 de Abril de 2013. [acesso 18 dez. 2017]. Disponível em: http:// www.forpedi.com.br/downloads/forpedi_ anexo_2204131434180.pdf

19. Brasil. Estatuto da Pessoa com Deficiência. [acesso 15 ago. 2015] Disponível em: http://www.planalto. gov.br/ccivil_03/_ato2015-2018/2015/lei/l13146.htm

20. Ruble LA, Dalrymple NJ, McGrew JH. Collaborative model for promoting competence and success for students with ASD. New York: Springer; 2012.

21. Ruble LA, McGrew JH, Toland M, Dalrymple NJ, Adams M, Snell-Rood C. Randomized control trial of COMPASS for improving transition outcomes of students with Autism Spectrum Disorder. J Autism Dev Disord. 2018;48(10):1-10.

22. Ruble LA, McGrew JH, Toland M, Dalrymple NJ, Jung LA. A randomized controlled trial of COMPASS web-based and face-to-face teacher coaching in autism. J Consult ClinPsychol. 2013;81(3):566-72.

23. Ruble LA, Dalrymple NJ, McGrew JH. The effects of consultation on individualized education program outcomes for young children with autism: the collaborative model for promoting competence and success. J Early Interv. 2010;32(4):286-301. 